\title{
Karakteristik Kualitas Air Limpasan di Daerah Urban Sebagai Sumber Pencemaran Air
}

\author{
Oleb : Sudarmadji
}

\section{ABSTRACT}

Urban development may result negative impact on the environment, especially on bydrological condition in the area, both on the surface and groundwater. Urban development will also cause transportation facilities to increase, such as road and vibicles. Human settlement may also cause volume of runoff to increase, beside degradation of water quality.

Chemical substances has been introduced when rain drops are formed as nucleous of condensation. When rain falls to the earth surface some gases in the atmosphere dissolved in the rainwater. Those situation make the rainwater is not purely H2O. Minerals in the solls, and rocks are dissolved in the water when the rainwater in contact with those matter, Consequently runoff which is formed by rainwater has some chemical substances and these substances will be constributed to receiving water bodies. Surface runoff drainning from urban land bas some chemical substances will be bigher in consentration in comparison to those runoff originated from rural area.

In this paper some investigations ralated to urban runoff in the some countries were reviewed, especially those related to quality of surface water drainning from urban area. Among the investiqations it could be observed that those runoff drainning from urban land have a significantly high of chemical substances such as $B O D, C O D$, suspended solids, total dissolved solids, chloride, phosphate, nitrate and coliform bacteria. In some cases, heavy metals such as Pb was also present in those kinds of runoff. Based on the findings, it is concidered that such investigation are urgently needed in Indonesian cities.

\section{INTISARI}

Perkembangan daerab kota dapat memberikan dampak negatif pada kondisi bidrologi, baik pada air permukaan maupun air tanab. Perkembangan daerab kota juga didukung oleb pertambangan sarana transportasi serta prasarananya, yaitu jalan raya dan kendaraan bermotor. Perkembangan daerab permukiman di daerab perkotaan juga menyebabkan bertambahnya volume limpasan dan penurunan kualitas air: Penelitian yang mengarab kepada dampak terbadap kondisi bidrologi, kbususnya pada kualitas air di beberapa negara di luar Indonesia dikaji, kbususnya yang menyangkut kualitas air permukaan yang berasal dari daerab kota. 
Zur kimia yang terdapat di dalam air sudab ada sejak awal terbentuknya esess air bujan dan pada proses jatubnya air bujan ke muka bumi. Terdapatsa ist kondensasi sudah menunjukkan masuknya zat lain ke dalam air bujan. 7 ats saxt bujan jatub ke muka bumi, berbagai macam gas terlarut di dalam air savas iersebut. Air bujan yang jabub di muka bumi melarutkan tanah, batuan Lus material lain yang ada di muka bumi, selanjutnya zat yang larut tersebut tutava aliran air yang terbentuk. Di daerab perkotaan material di tanab pekarangan dan jalan raya merupakan sumber pencemar yang sangat berarti.

Beberapa penelitian menunjukkan babwa air limpasan yang berasal dari samab perkotaan, baik yang berasal dari jalan raya maupun dari pekarangan manpunyai kadar zat kimia yang cukup tinggi dan mempunyai potensi yang cuisp sebagai pencemar bagi badan air penerima limpasan tersebut. Pencemar erselout dilibat dari BOD, COD, kadar zat tersuspensi, kadar zat terlarul, klorida nosfas, nitrat dan bakteri bentuk coli. Babkan ada beberapa kadar logam berat eperti Pb yang terdeteksi pada limpasan ini.

Mengacu kepada basil penelitian di luar negeri nampaknya penelitian di Indonesia semacam itu perlu pula dilakukan, mengingat babva perkembangan bota di Indonesia pesat juga.

\section{Pendahuluan}

Kota dengan segala aktivitasnya te. lah banyak diketahui sebagai salah satu sumber pencemaran air. Pencemaran in dapat terjadi pada air permukaan (air sungai) maupun pada air tanah Sumber utama pencemaran air di dacrah kota biasanya adalah dari sektorsektor rumah tangga, sektor perdagangan maupun sektor industri. Pusatpusat pelayanan umum juga dapat merupakan sumber pencemaran air ini. Pencemar tersebut berujud limbah, baik padat, cair maupun gas. Sudah banyak penelitian yang mengarah kepada masalah pencemaran ini di daerah perkotaan, seperti yang dilakukan oleh peneliti terdahulu Sudarmadji, (1991) meneliti kemungkinan akibat limbah terhadap kualitas airtanah di Kotamadya Yogyakarta, Sugeng Martopo, 1986 meneliti juga pencemaran air baik airtanah maupun air permukaan di kota yang sama

Pada dasarnya para peneliti berpen- dapat bahwa pencemaran air di daerah kota itu paling banyak discbabkan oleh limbah dari sektor kegiatan kota dan sektor rumah tangga. Walaupun demikian bukan berarti bahwa sumber pencemaran air tersebut hanya berasal dari dua hal tersebut di atas. Betapapun kecilnya sumber pencemar lain mempunyai andil dalam pencemaran air di daerah perkotaan.

Kegiatan kota menyangkut berbagai macam aspek, yang kesemuanya dapat memberikan andil pencemar kepada air. Beberapa hal sudah disebutkan di atas yaitu sektor rumah tangga dan industri. Sektor lalu lintas dapat pula merupakan sumber pencemar air yang perlu diperhatikan. Jalan raya dapat pula merupakan sumber pencemar air yang potensial, karena jalan raya tidak hanya berfungsi sebagai sarana lalu lintas saja, tetapi jalan ini dapat digunakan untuk kegiatan lain seperti berjualan (khususnya di Indonesia), tempat parkir dan lain sebagainya. Ceceran minyak oli, debu dan sampah banyak dijumpai di jalan raya. 
Penelitian semacam ini memang masih langka dilakukan, andaikata dilakukan baru mempunyai skala kecil. Dengan makin berkembangnya daerah-daerah perkotaan baru, maka aspek pencemaran air termasuk yang bersumber dari jalan raya akan makin perlu diperhatikan. Dalam tulisan ini akan dicoba untuk mengkaji beberapa hasil penelitian yang berkaitan dengan masalah kualitas air dari daerah perkotaan khususnya yang bersumber dari limpasan (runoff) di daerah kota, baik yang dilakukan di luar negeri maupun prospeknya apabila penclitian semacam ini dilakukan di Indonesia.

Dari Air Hujan Menjadi Air Limpasan

\subsection{Presipitasi (Hujan)}

Pada dasarnya air merupakan ikatan antara 2 atom hidrogen dan satu atom oksigen, sehingga apabila kita menyebut air, maka konotasi kita air tersebut mempunyai susunan $\mathrm{H} 2 \mathrm{O}$. Walaupun demikian air di alam ini (natural water) tidak hanya mempunyai komposisi kimia sebagai 1120 saja. Air hujan sekalipun yang secara alami merupakan air termurni tidak pernah mempunyai susunan kimia murni sebagai H2O. Semenjak permulaan terjadi proses pembentukan hujan dengan adanya inti kondensasi pada saat awal terjadinya proses kondensasi, air sudah tercampur dengan zat lain. Ketika hujan jatuh ke muka bumi, berbagai macam gas akan larut di dalamnya. Gas dari kegiatan volkanik, emisi gas dari industri, lalu lintas dan kegiatan rumah tangga sebagian larut di dalamnya dan terbawa jatuh ke muka tanah. Apabila air hujan sendiri sudah membawa gas terlarut di dalamnya, partikel debu dan zat kimia lain, maka air hujan bukan lagi merupakan $\mathrm{H} 2 \mathrm{O}$ murni. Belum lagi termasuk hujan yang jatuh di atas tumbuh-tumbuhan, komposisinya tentu akan berbeda.

\subsection{Limpasan}

Ketika hujan jatuh ke permukaan tanah tenaga mekaniknya yang berupa tenaga tetesan air hujan (tenaga gravitasi) menyebabkan agregat tanah terdispersi menjadi partikel yang lebih halus. Pada saat itu pula sudah terjadi proses erosi percik (splash erosion) terhadap tanah. Hasil erosi ini terangkut sebagai muatan sedimen, yang diendapkan di tempat yang lebih rendah. Zat-zat kimia juga terlarut di dalamnya dan terbawa pula dalam aliran air tersebut. Di daerah kota tidak hanya batuan yang larut di dalamnya tetapi lebih dari itu; ceceran sampah dari kegiatan rumah tangga serta limbah dapat menyumbangkan zat kimia kepada air yang melaluinya. Penggunaan jalan raya sebagai sarana transportasi menyebabkan banyak pencemar yang berasal dari sisa emisi kendaraan bermotor, ceceran oli, bensin, debu dari gesekan ban, dan bahkan lebih dari itu. Penggunaan jalan raya digunakan juga untuk kepentingan lain, seperti untuk berjualan dan parkir menyebabkan pula kompleksnya sumber pencemar yang berasal dari jalan raya ini. Kendaraan andong masih menggunakan kuda sebagai tenaga penggerak yang sering masih membuang kotorannya (hajat. nya) di jalan raya tanpa dapat terkontrol.

Oleh sebab itu semua yang diperkirakan di atas akan menyebabkan tingginya kadar pencemaran pada air limpasan. Pencemaran ini dapat terbawa ke air sungai, bahkan dengan berbagai cara dapat pula meresap ke dalam airtanah. 


\subsection{Limpasan dari pekarangan}

Kota dilengkapi dengan jalan raya sebagai pendukung kegiatan kota, khususnya transportasi dan komunikasi. Jalan raya yang baik selalu dilengkapi dengan sarana drainase air hujan di kanan kirinya, agar air hujan yang tidak mampu meresap ke dalam tanah dapat tersalur dan tertampung olch saluran drainase itu. Dalam perencanaan drainase ini biasanya sudah cukup mempertimbangkan kapasitas tampung saluran dengan memperhitungkan curah hujan, topografi, dan faktor-faktor lain termasuk hidraulika saluran. Saluran itu dirancang mampu untuk menampung limpasan yang dihasilkan oleh hujan dengan periode ulang tertentu. Walaupun demikian sering dijumpai bahwa saluran di daerah kota tidak mampu menampung limpasan tersebut, disebabkan antara lain oleh:

a) sampah dari daerah urban yang menyumbat saluran;

b) sedimen yang berasal daerah sekitarnya;

Tidak jarang limpasan dari pekarangan masuk ke dalam selokan ini, tetapi tidak mengalir langsung ke selokan itu. Air mengalir masuk melalui lobang inlet saluran masuk ke dalam. nya. Apabila lobang inlet ini tersumbat, justru akan menyebabkan banjir di jalan raya itu sendiri. Limpasan yang berasal dari pekarangan ini membawa sedimen yang cukup besar. Apabila lim. pasan dari pekarangan dapat dicegah supaya tidak mencapai jalan raya, beberapa keuntungan dapat diperoleh:

a. jalan raya tidak banjir;

b. sedimentasi tidak terjadi di jalan raya; c. debu tidak terdapat dan berhamburan di jalan raya;

d. lalu lintas dan kesehatan (terutama mata) tidak terganggu.

\subsection{Airtanah}

Airtanah bersumber dari hujan pula setelah melalui berbagai proses dalam daur hidrologi. Di daerah urban masih banyak airtanah yang digunakan sebagai persediaan air domestik. Oleh sebab itu airtanah penting untuk diperhatikan kelestariannya. Daerah imbuh (rechange area) airtanah dapat hanya berasal dari daerah itu sendiri atau dapat pula berasal dari dacrah yang terle. tak jauh di hulu. Apabila imbuh airtanah berasal dari daerah itu, lebih-lebih di daerah kota, maka airtanah clari pekarangan dan sekitar jalan raya dapat memberikan/menaikkan jumlah airtanah di daerah itu, tetapi di samping itu limpasan juga dapat memberikan zat pencemar ke dalam airtanah. Sumbangan pencemar kepada airtanah di daerah yang sama, dapat terbawa juga ke tempat yang lcbih jauh ke hilir.

\section{Karakteristik Kualitas Air Limpasan di Daerah Urban}

\subsection{Hasil penelitian terdahulu}

Kualitas air di daerah perkotaan pada umumnya lebih jelek dibandingkan kualitas air di daerah pedesaan. Hal ini sebagai konsekuensi kegiatan penduduk di daerah kota seperti telah disebutkan di muka. Beberapa hasil penelitian kualitas air di daerah kota, baik air limpasan maupun air limbah yang dilakukan oleh beberapa peneliti ditunjukkan pada Tabel 1 . 
Tabel 1. Karakteristik Kualitas Air Limpasan di Dacrah Urban

\begin{tabular}{lllllll}
\hline Parameter & & $\begin{array}{l}\text { Musgrave } \\
\text { Avemue } \\
\text { Drain *) }\end{array}$ & $\begin{array}{l}\text { Powells } \\
\text { Creek*) }\end{array}$ & $\begin{array}{l}\text { Bunne- } \\
\text { rong } \\
\text { SwC*) }\end{array}$ & $\begin{array}{l}\text { Durham } \\
\text { DC **) }\end{array}$ & $\begin{array}{l}\text { Naismith } \\
\text { Ditch ***) }\end{array}$ \\
\hline BOD & $(\mathrm{mg} / \mathrm{l})$ & 30 & 18 & 28 & 14,5 & 11,4 \\
COD & $(\mathrm{mg} / \mathrm{l})$ & - & - & - & 179 & 41 \\
Padatan tersusp & $(\mathrm{mg} / \mathrm{l})$ & 269 & 236 & 275 & 2730 & 974 \\
Padatan terlarut & $(\mathrm{mg} / \mathrm{l})$ & 120 & 118 & 137 & - & 275 \\
Cl & $(\mathrm{mg} / \mathrm{l})$ & - & - & - & 12,6 & - \\
Posfat total & $(\mathrm{mg} / 1)$ & 2,98 & 1,60 & 2,10 & 0,58 & - \\
NO3 & $(\mathrm{mg} / \mathrm{l})$ & 0,78 & 0,96 & 0,61 & - & 4,4 \\
Pb & $(\mathrm{ppb})$ & - & - & - & 0,32 & - \\
pH & 6,78 & 6,98 & 6,47 & - & 7,7 & \\
Faecal coliform & $(\mathrm{MPN} / 100 \mathrm{ml})$ & $41 \times 104$ & $41 \times 104$ & $6,5 \times 104$ & $3 \times 104$ & - \\
Total coliform & $(\mathrm{MPN} / 100 \mathrm{ml})$ & $5,6 \times 106$ & $2,2 \times 106$ & $2 \times 106$ & - & \\
\hline
\end{tabular}

Sumber

*) : Cordery, 1976.

**) : Bryan, 1972

***) : Angino et al, 1972.

Dari hasil penelitian terdahulu (Tabel 1) ternyata dapat dikctahui bahwa limpahan yang berasal dari daerah urban cukup potensial scbagai sumber pencemar. Padatan tersuspensi, padatan terlarut dan kandungan bakteri bentuk coli sangat mencolok tingginya. Lebih menarik lagi bahwa yang didapatkan di Durham DC, bahwa air limpasan sudah mengandung $\mathrm{Pb}$ sebesar $0,32 \mathrm{ppb}$. Sumber $\mathrm{Pb}$ ini diperkirakan ada hubungan dengan emisi gas dari knalpot kendaraan bermotor.

Kadar pencemar tersebut tidak sama selamanya terjadi aliran sesudah hujan. Pada umumnya kadar pencemar yang tinggi tercapai sebelum aliran tersebut mencapai puncaknya. Ketika aliran mencapai puncaknya, justru kadar pencemar sudah menurun, dan seterusnya akan kembali menjadi rendah. Jadi justru pada saat- saat awal terjadinya aliran itulah kadar pencemar yang tinggi akan dijumpai.

Angka bakteri coli yang cukup tinggi yang terdapat pada limpasan dimungkinkan oleh adanya tinja dari binatang yang sering membuang kotoran di jalan raya, dan kemudian terbawa aliran pada saat terjadi hujan tersebut, sedangkan debu yang terakumulasi di jalan raya menyebabkan tingginya kadar zat tersuspensi dalam air limpasan tersebut,

Kadar zat pencemar yang terbawa oleh limpasan yang bersumber dari jalan raya maupun yang berasal dari lahan pekarangan dapat dihitung apabila jumlah kejadian hujannya sclama wak. tu tertentu diketahui serta kadar zat pencemar dari kedua sumber limpasan tersebut diketahui. Hal ini telah dilakukan oleh Cordery (1976) yang menyebutkan bahwa BOD yang terangkut selama setahun di Musgrave Avenue oleh aliran air sehabis hujan scbesar 
$17,2 \mathrm{~kg} / \mathrm{ha} / \mathrm{th}$, padatan tersuspensi sebesar $286,3 / \mathrm{ha} / \mathrm{th}$, amonia sebesar $2.29 \mathrm{~kg} / \mathrm{ha} / \mathrm{th}$ dan posfat sebesar 2,86 $\mathrm{kg} / \mathrm{ha} / \mathrm{th}$. Di Durham DC angka tersebut ternyata lebih tinggi, yaitu BOD $94.15 \mathrm{~kg} / \mathrm{ha} / \mathrm{th}$, COD sebesar 1165,7 $\mathrm{kg} / \mathrm{ha} / \mathrm{th}$, padatan terlarut sebesar $17821,2 / \mathrm{ha} / \mathrm{th}$, klorida sebesar 81,82 $\mathrm{kg} / \mathrm{ha} / \mathrm{th}$, posfat sebesar $3,81 \mathrm{~kg} / \mathrm{ha} / \mathrm{th}$ dan $\mathrm{Pb}$ sebesar $2,13 \mathrm{~kg} / \mathrm{ha} / \mathrm{th}$.

Dari angka-angka tersebut ternyata pencemar yang terangkut oleh air lim. pasan dari jalan raya dan lahan pekarangan di daerah urban selama setahun cukup tinggi, yang berarti bahwa sumbangannya kepada tubuh air penerima juga perlu diperhitungkan.

\section{Beberapa pemikiran tentang pe- nelitian di Indonesia}

Suatu fakta bahwa penelitian masalah kualitas air limpasan di daerah kota belum lengkap, bahkan boleh dikatakan masih langka. Mendasarkan pada fakta tersebut didukung oleh penting artinya penelitian yang menyangkut kualitas air di daerah urban. khususnya tentang limpasan, maka dapat dimengerti bahwa penelitian scmacam itu perlu dilakukan di Indonesia Selama ini penelitian yang sudah tersentuh adalah penelitian yang menyangkut pencemaran air dalam hubungannya dengan industri, dengan kegiatan rumah tangga serta dengan pertanian maupun kegiatan pertambangan.

Mengingat hasil penclitian di luar negeri bahwa terdapat kadar pencemar termasuk $\mathrm{Pb}$ yang cukup berarti di dalam air limpasan yang berasal dari jalan raya, maka tidak tcrtutup kemungkinan bahwa di Indonesia akan mendapatkan hasil yang mirip. Lebih. lebih apabila diingat bahwa kepadatan lalu lintas di jalan-jalan kota di In- donesia sangat tinggi.

Kadar bakteri coli juga menunjukkan angka yang sangat tinggi. Ini menunjukkan bahwa tingkat pencemaran tinja di jalan raya juga cukup tinggi. Sumber dari pencemar ini mungkin adalah kotoran binatang seperti anjing dan kucing. Di beberapa kota di Indonesia masih digunakan andong dengan kuda sebagai penghelanya. Tidak tertutup kemungkinan kotoran dari kuda tersebut juga menyumbangkan kadar bakteri coli yang cukup tinggi, yang perlu untuk diungkapkan lebih rinci.

Baku mutu lingkungan tentang air dan udara sudah ditetapkan, tetapi sampai pada saat ini belum dapat berlaku secara efektif khususnya mengenai baku mutu udara. Oleh sebab itu belum ada kontrol yang efisien terhadap emisi dari kenclaraan bermotor di jalan raya, yang kémungkinan besar juga merupakan penyebab pencemaran air yang berasal dari daerah kota.

\section{Penutup}

Beberapa hal dari hasil telaah penelitian yang menyangkut kualitas air limpasan di daerah perkotaan dapat dibcrikan rumusan sebagai berikut ini.

1. Perkembangan kota telah tcrbukti memberikan dampak negatif pada kualitas air permukaan yang berasal dari jalan raya dan lahan pekarangan. Selanjutnya air limpasan tersebut dapat menyumbang pencemar kepada badan air penerima air tersebut, baik air sungai maupun airtanah.

2. Bahwa besarnya hujan yang membentuk aliran merupakan faktor yang berpengaruh terhadap besarnya kadar pencemar di dalain air 
limpasan, terbukti dari variasi pencemaran menurut waktu, dan intensitas hujan yang berbeda-beda yang menjadi penyebab terjadinya limpasan itu. Walaupun bila dibandingkan dengan air limbah domestik dan limbah industri kadar pencemar dalam limpasan masih rendah namun total pencemar yang terangkut dari daerah kota selama setahun ternyata cukup tinggi.

3. Penelitian tentang karakteristik air limpasan dari daerah kota di Indonesia masih belum ditangani. oleh sebab itu penelitian semacam itu perlu dilakukan di Indonesia.

4. Mengingat bahwa sumber airtanah dapat terkontaminasi oleh pence. mar dari jalan raya, maka pemeliharaan dari saluran drainase perlu diperhatikan agar jangan sampai air yang berasal dari limbah dan air limpasan dari jalan raya dapat merembes masuk ke dalam airtanah.

\section{Daftar Pustaka}

Angino, E.E., Magnuson, L.M. and Stewart, G.F. 1972. Effects of Urbanisation on Stormwater Runoff Quality: A Limited Experiment, Naismith Ditch, Lawrence, Kansas. Water Resources Research, Vol. 8 pp. 135-140.

Bryan, E.H., 1972. Quality of Storwater Drainage from Urban Land. Water Resources Bulletin, Vol. 8 June, pp. 135-140.

Cordery, I. 1976. Evaluation and Improvement of Quality Characteristic of Urban Stormwater: University of New South Wales, Water Resources laboratory Report, October, No. 147.

Perlmutter, n.M. and Guerrera, A.A. 1970. Detergent and Associated Contaminants in Groundwater at Three Public-Supply Wells Fields in Southwestern Suffolk Country, Long Island, New York. U.S. Geological Water Supply Paper, No. 2001-3, pp B1-B22.

Ruanc, R.J., and Fruh, E.G. 1973. Effects of Watershed Development on Water Quality. Journal of American Water Work Association, Vol. 65 May, pp. 358 363.

Sudarmadji 1991. Agihan Geografi Sifat Kimiawi Airtanah Bebas di Kotamadya Yogyakarta. Disertasi, Universitas Gadjah Mada, Yogyakarta.

Sugeng Martopo, Slamet Suprayogi dan Budi Sulaswono, 1986. Penelitian Pencemaran Air di Kotamadya Yogyakarta. Lembaga Penelitian Universitas Ga. djah Mada, Yogyakarta. 